US Army Corps of Engineers ${ }_{\circledast}$

Engineer Research and

Development Center

Ecosystem Management and Restoration Research Program

\title{
Threatened, Endangered, and At-Risk Species for Consideration into Climate Change Models in the Northeast
}

Jacob F. Jung, Michael P. Guilfoyle, Austin V. Davis,

September 2021

Christina L. Saltus, Eric R. Britzke, and Richard A. Fischer

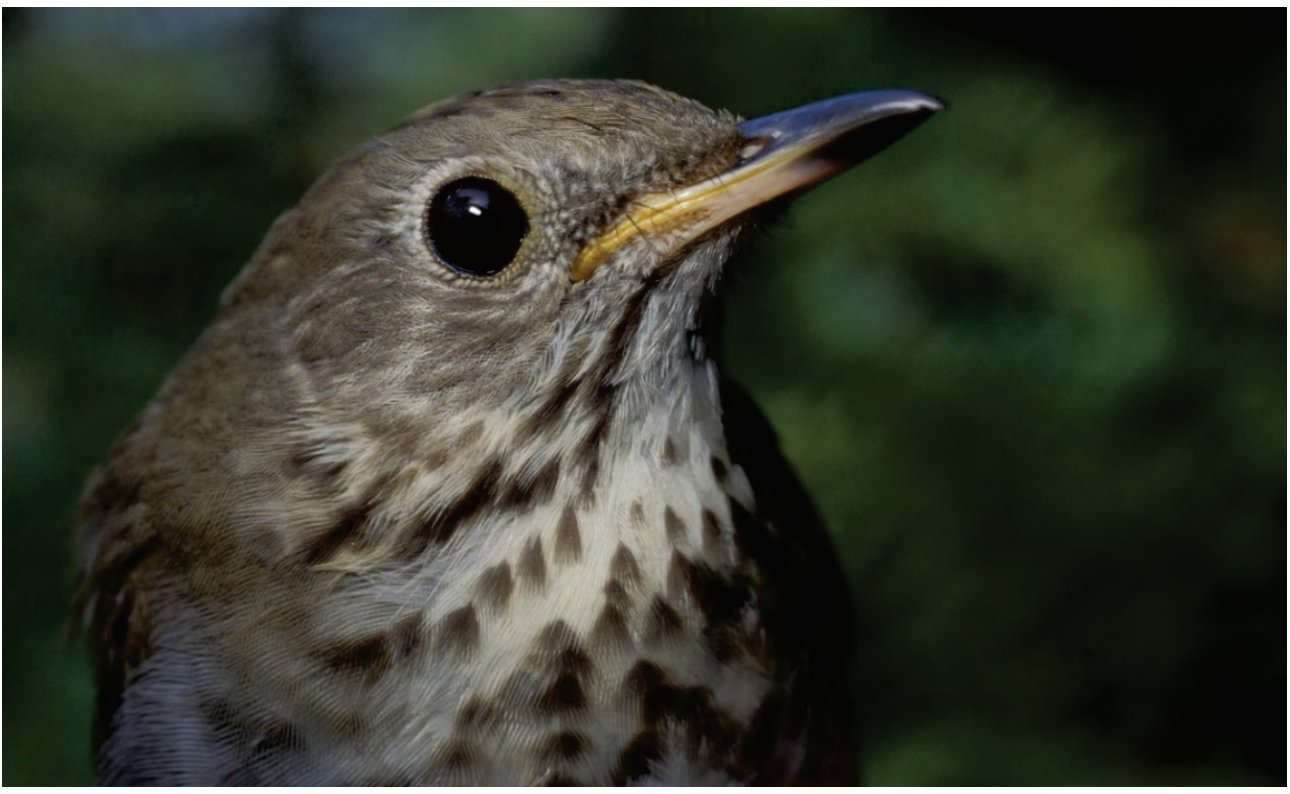


The U.S. Army Engineer Research and Development Center (ERDC) solves the nation's toughest engineering and environmental challenges. ERDC develops innovative solutions in civil and military engineering, geospatial sciences, water resources, and environmental sciences for the Army, the Department of Defense, civilian agencies, and our nation's public good. Find out more at www.erdc.usace.army.mil.

To search for other technical reports published by ERDC, visit the ERDC online library at https://erdclibrary.on.worldcat.org/discovery.

Photo Credit: Tim Laman/Audubon. 


\section{Threatened, Endangered, and At-Risk Species for Consideration into Climate Change Models in the Northeast}

Jacob F. Jung, Michael P. Guilfoyle,

Christina L. Saltus, Eric R. Britzke, and Richard A. Fischer

Environmental Laboratory

U.S. Army Engineer Research and Development Center

3909 Halls Ferry Road

Vicksburg, MS 39180-6199

Austin V. Davis

Geotechnical and Structures Laboratory

US Army Engineer Research and Development Center

3909 Halls Ferry Road

Vicksburg, MS 39180-6199

Final report

Approved for public release; distribution is unlimited.

Prepared for U.S. Army Corps of Engineers, Ecosystem Management and Restoration

Research Program

Vicksburg, MS 39180

Under "Data Assessment of Species and Habitat Migration due to Climate Change."

Funding Account Code U4368936, AMSCO Code 031342 


\section{Abstract}

This special report provides a selection process for choosing priority species using the specific focus of high-elevation, forested habitats in the North Atlantic to demonstrate the process. This process includes criteria for choosing invasive species to incorporate into models, given the predicted spread of invasive plant species because of climate change. Discussed in this report are the US Army Corps of Engineers' Threatened and Endangered Species Team portal, the US Fish and Wildlife Service's Information for Planning and Consultation Portal, the nonprofit organization Partners in Flight's watch list, the US Geological Survey's Biodiversity Information Serving Our Nation model, and NatureServe's interagency effort Landfire. The data linked this montane habitat with a species of conservation concern, Cartharus bicknelli and the endangered squirrel Glaucomys sabrinus as target species and with Elaeagnus umbellate, Robinia pseudoacacia, Rhamnus cathartica, and Acer planoides as invasive species. Incorporating these links into the climate change framework developed by Davis et al. (2018) will create predictive models for the impacts of climate change on TER-S, which will affect land management decisions in the region.

DISCLAIMER: The contents of this report are not to be used for advertising, publication, or promotional purposes. Citation of trade names does not constitute an official endorsement or approval of the use of such commercial products. All product names and trademarks cited are the property of their respective owners. The findings of this report are not to be construed as an official Department of the Army position unless so designated by other authorized documents. 


\section{Contents}

Abstract........................................................................................................................... if

Figures and Tables................................................................................................... iv

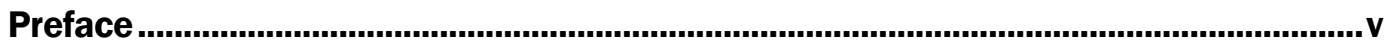

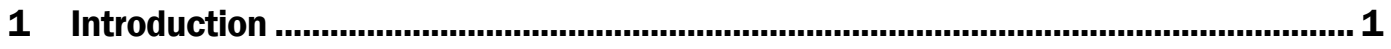

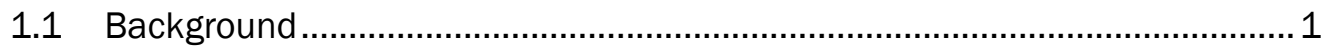

1.2 Objective(s) ................................................................................. 3

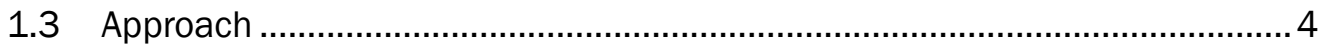

2 Species Impacting US Army Corps of Engineers (USACE) Operations in

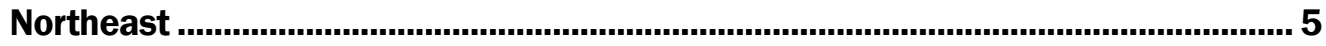

2.1 USACE test portal for threatened and endangered species costs .................5

2.2 Information for Planning and Consultation (IPaC) ..................................... 6

2.3 Partners in Flight (PIF)......................................................................... 8

2.4 Biodiversity Information Serving Our Nation (BISON), US Geological

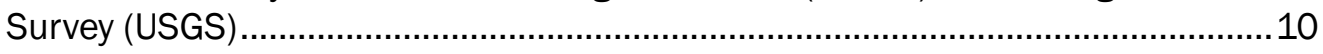

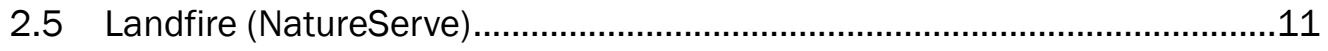

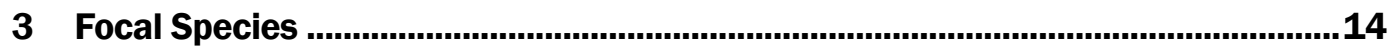

3.1 Bicknell's thrush (Catharus bicknelli) ......................................................15

3.2 Carolina northern flying squirrel (Glaucomys sabrinus coloratus) ................16

4 Invasive Species ................................................................................................................... 17

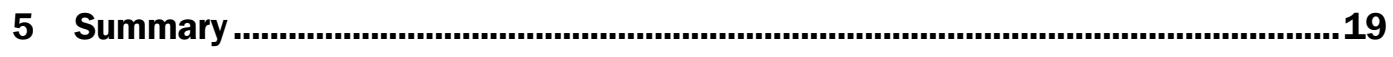

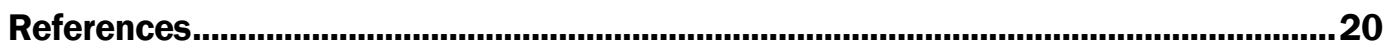

\section{Report Documentation Page}




\section{Figures and Tables}

\section{Figures}

Figure 1. A screenshot of the US Army Corps of Engineers (USACE) Threatened and Endangered Species Costs web portal, demonstrating the capability to procure expenditure information by species, year, district, business lines and expense types.

Figure 2. A screenshot of the US Geological Survey (USGS) Biodiversity Information Serving Our Nation (BISON) web portal, demonstrating the capability to procure information on species' distributions and habitats.

Figure 3. Locations and distribution of Bicknell's thrush in the USACE NAD overlaying the ecoregion land cover layer from Landfire (NatureServe).

Figure 4. The Bicknell's thrush is an uncommon, high elevation species found in the NAD region that may be sensitive to global climate change (Photo Credit: Tim Laman/Audubon).

Figure 5. The Carolina northern flying squirrel is a federally listed species that could shift into the USACE NAD jurisdiction as a result of global climate change (Photo Credit: USFWS)

\section{Tables}

Table 1. List of threatened and endangered species that currently inhabit or that have the potential to inhabit USACE reservoirs in the North Atlantic Division (NAD) according to the Information for Planning and Consultation (IPaC), as well as USACE cost expenditure for fiscal years 2013-2016 (FY13-16) according to the USACE Threatened and Endangered Species Team (TEST) portal for expenditures.

Table 2. Ranking of bird species by total vulnerability score on the Partners in Flight (PIF) 2016 Watchlist and that inhabit or potentially inhabit USACE reservoir properties within the NAD according to the US Fish and Wildlife Service (USFWS) $\mathrm{IPaC}$ report.

Table 3. Percentage of breeding Bicknell thrush locations within each ecological system defined in the Landfire (NatureServe) Existing Vegetation Types.

Table 4. Invasive terrestrial plants in the NAD highly ranked by the US Forest

Service and likely to negatively affect selected focal species (NatureServe 2017). 


\section{Preface}

This study was conducted for the U.S. Army Corps of Engineers, Ecosystem Management Restoration Research Program under Funding Account Code U4368936 and AMSCO Code 031342. The program monitor was Trudy Estes.

The work was performed by the Ecological Resources Branch of the Ecosystem Evaluation and Engineering Division, US Army Engineer Research and Development Center, Environmental Laboratory (ERDCEL). At the time of publication, Dr. Harley McAlexander was Acting Chief; Mark Farr was Division Chief; and Dr. Jennifer Seiter-Moser was the Technical Director for Civil Works Program. The Deputy Director of ERDC-EL was Dr. Brandon Lafferty, and the Director was Dr. Edmond J. Russo.

The Commander of ERDC was COL Teresa A. Schlosser and the Director was Dr. David W. Pittman. 


\section{Introduction}

This special report is a part of the work unit "Data Assessment of Species and Habitat Migration due to Climate Change" and outlines the selection process for choosing priority species relevant to US Army Corps of Engineers (USACE) ecosystem restoration projects within the North Atlantic Division (NAD). Data on selected species will be incorporated into a model (Davis et al. 2019) designed to predict changes in habitat availability as climate change progresses.

\subsection{Background}

Species unable to adapt to the current rate of environmental change will likely experience significant declines. Even species currently common may experience population declines, resulting in a change to their conservation status and the potential for increased regulatory restrictions. Climate change also may exacerbate the expansion of invasive or disease-carrying species into areas not previously found (Monzon, Moyer-Horner, and Palamar 2011). The risk of extinction for many species already listed under the Endangered Species Act (ESA) of $1973^{1}$ or by the International Union for Conservation of Nature (IUCN) may increase, while other species currently of conservation concern may be formally added to lists of imperiled species. Climate change has already caused documented changes to some species distributions, either by expansion or shifts with current habitat distributions (Parmesan and Yohe 2003). Data from vegetative flowering dates (Visser and Both 2005) and bird migration departure and arrival dates (Kirby et al. 2008; Cary 2009; Gill et al. 2014) indicate significant impacts from global warming that may complicate and compromise current resource management and conservation efforts (Monzon, Moyer-Horner, and Palamar 2011). Indeed, by affecting the phenology, distribution and physiological condition of plants and animals, the negative impacts of climate change will likely increase extinction rates and significantly decrease overall global biodiversity (Bellard et al. 2012). Improving conservation outcomes require new approaches: by predicting the impacts of global climate change and subsequent potential changes to species' regional or national conservation status, these data will anticipate 
heightened legal obligations and increased time and cost expenditures for conservation efforts on USACE project lands in the hope of preparing for them in advance.

Numerous modeling tools are available that aim to predict through shifting distributions of habitat ecoregions the consequences of global climate change on large groups of animals or on large portions of North America (Davis et al. 2019). With uncertainty of changing environmental conditions, a model that provides a level of predictability for how species' ranges will shift in the face of climate change will provide resource managers an important tool for managing natural resources on USACE project lands and for future ecosystem restoration projects nationwide. Important characteristics of global climate change predictive models include integrated variables of possible atmospheric change derived from trends in temperature, precipitation, oceanic atmosphere conditions, and extreme weather events (Moss et al. 2010). These climate models can then be linked to species distribution models to predict current and future changes on a species' distribution. In general, landscapes and ecoregions change slowly. Predicting habitat or distribution shifts for a species within ecoregions presents a difficult challenge fraught with bias, which often yields inaccurate predictions (Thomas 2010). Spatial extent of ecoregions and a species' distribution within regions, combined with lag time responses to climate change, may also introduce uncertainty. Nevertheless, developing a methodological framework for predicting the impacts of climate change on threatened, endangered, and at-risk species (TER-S) will inform the USACE decision-making process for future conservation and restoration efforts.

Davis et al. (2019) outlined a framework incorporating integrated assessment models, climate models, species distribution models, and ecological niche models. This special report complements that effort by outlining the approach to identify specific species useful for demonstrating this framework. Incorporating specific species demonstrates the utility and effectiveness of the model and will help USACE in its task to monitor and conserve TER-S on more than 12 million ac (5 million ha). ${ }^{2}$ Moreover, the spread of existing invasive species or the introduction of new invasive

\footnotetext{
2 For a full list of the spelled-out forms of the units of measure used in this document, please refer to US Government Publishing Office Style Manual, 31st ed. (Washington, DC: US Government Publishing Office, 2016), 248-52, https://www.govinfo.gov/content/pkg/GPO-STYLEMANUAL-2016/pdf/GPOSTYLEMANUAL-2016.pdf.
} 
species will further complicate the management of these lands. In order to predict the potential changes due to climate change, the framework developed by Davis et al (2019) will be tested on TER-S and the potential spread of invasive species that may potentially impact future USACE natural resource management and restoration objectives in the NAD. After successful demonstration on the selected species within the model for the $\mathrm{NAD}$, the overall approach for developing the model can be applied to other project lands managed by the USACE nationwide for management of other species.

This demonstration effort will focus on terrestrial TER-S inhabiting higher elevation forest communities to demonstrate the utility of the model; however, the final model will include TER-S that inhabit other terrestrial communities both within the NAD and throughout the continental United States. Wildlife populations in high elevation montane habitats are experiencing ongoing shifts in habitat utilization and distribution more than other terrestrial habitats. The net result of such range and habitat shifts will likely include overall loss of biodiversity, local extirpations, and potential extinctions of some species (Iverson et al. 1999; Baltensperger and Huettmann 2015). The extent of high elevation areas within the NAD, as well as the noted sensitivity of these habitats to global climate change, offers a good opportunity to test the model framework of Davis et al. (2019) on specific species in the region.

\subsection{Objective(s)}

The "Data Assessment of Species and Habitat Migration due to Climate Change" work unit aims to predict how TER-S ranges may shift during significant changes in climate and how these changes may impact land management decisions by USACE project managers. We describe the various selection criteria and ranking systems available for selecting priority TER-S to be included in a climate change model for the NAD. The projected spread of invasive plant species during climate change could also impact TER-S habitat availability; therefore, we present criteria for selection of groups of invasive species to be considered for inclusion into climate change models. The selection criteria we outline also applies to other regions of the country, benefiting other USACE districts and divisions planning future ecosystem restoration projects that may include TER-S habitat management. 


\subsection{Approach}

We use two specific target species (Cartharus bicknelli and Glaucomys sabrinus) to demonstrate the utility of the climate change framework developed by Davis et al. (2019) in guiding planning and landmanagement decisions for TER-S habitats monitored and managed by USACE in the North Atlantic. 


\section{Species Impacting US Army Corps of Engineers (USACE) Operations in Northeast}

Many tools are available for investigating which species are most likely to impact a project within a particular region of the country. Factors such as level of imperilment (for example, threatened or endangered species according to the ESA), mandated regulatory restrictions, current cost expenditures, recovery potential, invasion of non-native invasive species or disease, or a limited geographic range subject to catastrophic events can determine the level of management necessary for different species within an area. In subsequent sections, we outline some of the tools that are useful in determining which species are most likely to adversely affect projects either currently or in the future.

\subsection{USACE test portal for threatened and endangered species costs}

The USACE Threatened and Endangered Species Team (TEST) has created a web portal (https://tescost.el.erdc.dren.mil/) that includes USACE expenditures for threatened and endangered species for all of USACE. Cost expenditure tables can be generated by year, district, business lines, expense types, and species. An example of an output table generated from the TEST Portal for Threatened and Endangered Species Costs is displayed below in Figure 1. USACE can use budget data for future budget planning to inform strategic organizational approaches to management and to inform basic TER-S cost questions across the USACE. 
Figure 1. A screenshot of the US Army Corps of Engineers (USACE) Threatened and Endangered Species Costs web portal, demonstrating the capability to procure expenditure information by species, year, district, business lines and expense types.

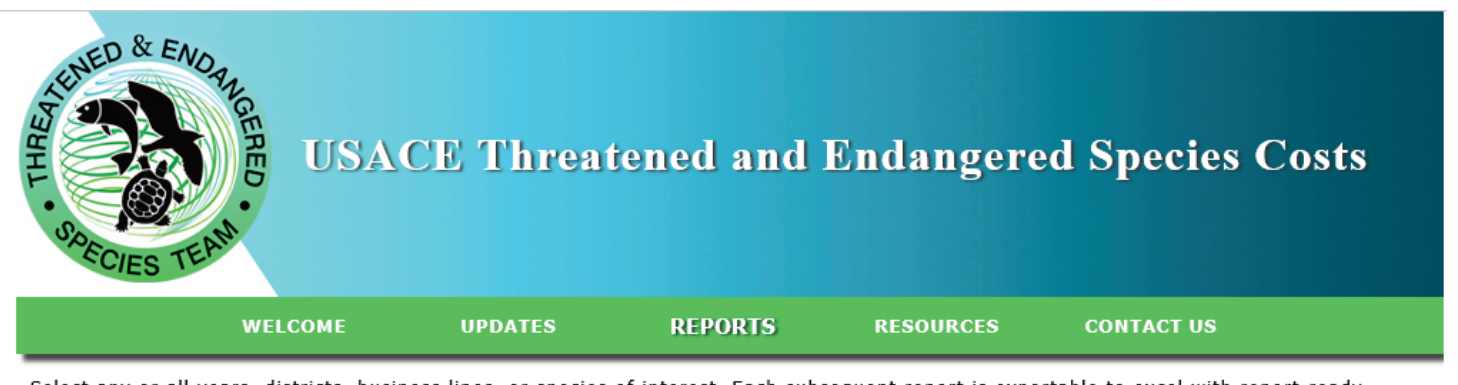

Select any or all years, districts, business lines, or species of interest. Each subsequent report is exportable to excel with report-ready graphs included.

\begin{tabular}{|c|c|c|c|c|c|}
\hline \multicolumn{2}{|c|}{ YEARS } & \multicolumn{2}{|c|}{ DISTRICTS } & \multicolumn{2}{|c|}{ BUSINESSLINES } \\
\hline 回 & Select all & 回 & Select all & $\nabla$ & Select all \\
\hline$\square$ & $200 /$ & $\square$ & Mobile & & \\
\hline 回 & 2008 & 回 & Nashville & $\nabla$ & Restoration \\
\hline 回 & 2009 & 四 & New England & V & Environment - \\
\hline 回 & 2010 & $\square$ & New Orleans & V & Stewardship \\
\hline 回 & 2011 & $\nabla$ & New York & V & Flood/Storm Risk \\
\hline 回 & 2012 & $\nabla$ & Norfolk & 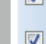 & $\begin{array}{l}\text { Management } \\
\text { Hydropower }\end{array}$ \\
\hline$\nabla$ & 2013 & 回 & North Atlantic & (7) & Multi-Purpose \\
\hline 目 & 2014 & $\square$ & Northwestern & $\nabla$ & Navigation \\
\hline 目 & 2015 & $\square$ & Omaha & $\checkmark$ & Recreation \\
\hline 目 & 2016 & 目 & Philadelphia & 同 & Donulatnry \\
\hline & enerate & & (5) Expor & & \\
\hline
\end{tabular}

\begin{tabular}{|c|c|c|c|c|c|}
\hline$\underset{\angle U \perp U}{\text { YEAR }}$ & $\begin{array}{l}\text { DISTRICT } \\
\text { ivew Liyra... }\end{array}$ & $\begin{array}{l}\text { BUSINESSLINE } \\
\text { neyuiatuiy }\end{array}$ & 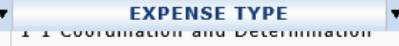 & $\begin{array}{l}\text { SPECIES } \\
\text { val, tuuiana }\end{array}$ & $\underset{\text { TOTAL, }}{\text { TOUU }}$ \\
\hline 2016 & New Engla... & Environment - Stewardship & 1-1 Coordination and Determination & Bat, Nothern Long-Eared & $\$ 10,100$ \\
\hline 2016 & New Engla... & Environment - Stewardship & 1-2 Site Visits and Inspections & Bat, Nothern Long-Eared & $\$ 7,900$ \\
\hline 2016 & New Engla... & Environment - Stewardship & $\begin{array}{l}2-1 \text { Inventory, Survey, and } \\
\text { Monitoring }\end{array}$ & Bat, Nothern Long-Eared & $\$ 10,000$ \\
\hline 2016 & New Engla... & Environment - Stewardship & $\begin{array}{l}\text { 2-5 Design for ESA Protection and } \\
\text { Conservation Measures }\end{array}$ & Bat, Nothern Long-Eared & $\$ 5,000$ \\
\hline 2016 & New Engla... & Environment - Stewardship & 4-1 Other Costs for this Species & Bat, Nothern Long-Eared & $\$ 11,900$ \\
\hline 2016 & New Engla... & Regulatory & 1-1 Coordination and Determination & Bat, Nothern Long-Eared & $\$ 1,000$ \\
\hline 2016 & New Engla... & Regulatory & 1-1 Coordination and Determination & Lynx, Canada & $\$ 80,000$ \\
\hline 2016 & New York & Regulatory & 1-1 Coordination and Determination & Bat, Indiana & $\$ 13,300$ \\
\hline 2016 & New York & Regulatory & 1-1 Coordination and Determination & Bat, Nothern Long-Eared & $\$ 32,680$ \\
\hline 2016 & Philadelphia & Regulatory & 1-1 Coordination and Determination & Bat, Indiana & $\$ 1,200$ \\
\hline 2016 & Philadelphia & Multi-Purpose & 1-1 Coordination and Determination & Bat, Nothern Long-Eared & $\$ 9,000$ \\
\hline 2016 & Philadelphia & Regulatory & 1-1 Coordination and Determination & Bat, Nothern Long-Eared & $\$ 9,000$ \\
\hline 56 Rec.... & & & & & $\$ 1,613,420$ \\
\hline
\end{tabular}

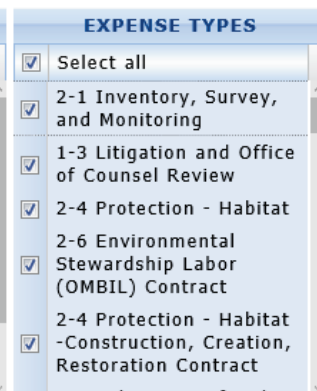

\begin{tabular}{|l|l|}
\hline \multicolumn{1}{|c|}{ SPECIES } \\
\hline Select all \\
\hline$\square$ Squirrel, Carolina northern flying \\
\hline$\square$ Squirrel, Delmarva Peninsula fox \\
$\square$ Squirrel, Mount Graham red \\
$\square$ Squirrel, northern Idaho ground \\
$\square$ Squirrel, Virginia northern flying \\
$\square$ Squirrel, Washington Ground \\
$\square$ Steelhead \\
$\square \begin{array}{l}\text { Stenogyne angustifolia } \\
\text { angustifolia } \\
\text { ctannmumn hifid }\end{array}$ \\
\hline$\square$
\end{tabular}
Restoration Contract angustifolia

\subsection{Information for Planning and Consultation (IPaC)}

The US Fish and Wildlife Service (USFWS) has created an online portal (https://ecos.fws.gov/ipac/), Information for Planning and Consultation (IPaC), to help those seeking assistance with impact analyses during National Environmental Policy Act3 (NEPA) environmental reviews. In particular, the IPaC allows users to set boundaries for a geographic region, called a 
project "footprint," either manually or via uploading of GIS shapefiles and receive lists of TER-S and any designated critical habitat, USFWS Birds of Conservation Concern, wetlands, and other biological resources that may be impacted by a proposed project. IPaC also assists project managers with consultation on any impacts to listed species that occur or potentially reside on project lands. We uploaded shapefiles of the 53 USACE reservoir boundaries in the NAD to evaluate which species currently or potentially could impact USACE lands according to IPaC. We have listed eleven species of interest within the NAD according to the 53 USACE reservoirs in that region (Table 1). We have summarized those species listed as either threatened or endangered under the ESA according to the number of occurrences for each species among the 53 USACE projects, and we listed the USACE expenditure within the NAD from fiscal years 2013-2016 (FY13-16). (Note that IPaC is a coarse filter for assessing the potential presence of species within a specified geography. If IPaC indicates a species' potential presence after a geographic search of a specified area, that alone does not confirm presence. Confirming the presence of target species still requires monitoring data from each project.)

Table 1. List of threatened and endangered species that currently inhabit or that have the potential to inhabit USACE reservoirs in the North Atlantic Division (NAD) according to the Information for Planning and Consultation (IPaC), as well as USACE cost expenditure for fiscal years 2013-2016 (FY13-16) according to the USACE Threatened and Endangered Species Team (TEST) portal for expenditures.

\begin{tabular}{|l|l|l|l|}
\hline Species & $\begin{array}{l}\text { \# of USACE reservoirs } \\
\text { with potential T/E } \\
\text { occurrence in NAD }\end{array}$ & $\begin{array}{l}\text { \% of USACE reservoirs } \\
\text { in NAD with species }\end{array}$ & $\begin{array}{l}\text { FY 13-16 USACE NAD } \\
\text { expenditure (\$K) }\end{array}$ \\
\hline $\begin{array}{l}\text { Northern long-eared bat } \\
\text { Myotis septentrionalis }\end{array}$ & 53 & 100 & 384 \\
\hline $\begin{array}{l}\text { Indiana bat } \\
\text { Myotis sodalis }\end{array}$ & 12 & 23 & 1,033 \\
\hline $\begin{array}{l}\text { Northeastern bulrush } \\
\text { Scirpus ancistrochaetus }\end{array}$ & 11 & 21 & 2 \\
\hline $\begin{array}{l}\text { Small whorled pogonia } \\
\text { Isotria medeoloides }\end{array}$ & 3 & 6 & 11 \\
\hline $\begin{array}{l}\text { Dwarf wedgemussel } \\
\text { Alasmidonta heterodon }\end{array}$ & 3 & 6 & 20 \\
\hline $\begin{array}{l}\text { Bog turtle } \\
\text { Glyptemys muhlenbergii }\end{array}$ & 3 & 6 & 252 \\
\hline $\begin{array}{l}\text { Gray bat } \\
\text { Myotis grisescens }\end{array}$ & 1 & 2 & 26 \\
\hline
\end{tabular}




\begin{tabular}{|l|l|l|l|}
\hline & $\begin{array}{l}\text { \# of USACE reservoirs } \\
\text { with potential T/E } \\
\text { occurrence in NAD }\end{array}$ & $\begin{array}{l}\text { \% of USACE reservoirs } \\
\text { in NAD with species }\end{array}$ & $\begin{array}{l}\text { FY 13-16 USACE NAD } \\
\text { expenditure (\$K) }\end{array}$ \\
\hline $\begin{array}{l}\text { Virginia big-eared bbat } \\
\text { Corynorhinus townsendii } \\
\text { virginianus }\end{array}$ & 1 & 2 & 26 \\
\hline $\begin{array}{l}\text { Shale barren rock cress } \\
\text { Arabis serotina }\end{array}$ & 1 & 2 & 0 \\
\hline $\begin{array}{l}\text { Smooth purple coneflower } \\
\text { Echinacea laevigata }\end{array}$ & 1 & 2 & 0 \\
\hline $\begin{array}{l}\text { Rusty patched bumblebee } \\
\text { Bombus affinis }\end{array}$ & 1 & 2 & 0 \\
\hline
\end{tabular}

\subsection{Partners in Flight (PIF)}

Partners in Flight (PIF) is a non-profit organization that includes support from over 150 collaborative organizations, including US federal agencies, in the Western Hemisphere. The organization focuses on landbird conservation and carries out research, planning, policy development, land management, monitoring, education, and public outreach with a goal of "keeping common birds common and helping species at risk through voluntary partnerships" (https://partnersinflight.org). PIF has developed a Watch List (Rosenberg et al. 2016) of North American landbirds to include those species that are most vulnerable and in need of conservation to increase populations. The current watch list (https://www.partnersinflight.org/resources/pif-watchlist-table-2016/) has identified 86 species that are at the highest level of conservation concern at the continental scale (Table 2). The list has three main categories: Red List-Recover; Yellow List "R"-Prevent Decline; Yellow List "D"-Reverse Decline. The Red List contains those species with extremely high vulnerability due to small population and range, high threats, and rangewide declines. The Yellow List "R" contains those species not declining but vulnerable due to small range or population and moderate threats. The Yellow List " $D$ " contains those species with population declines and moderate to high threats. Species vulnerability is assessed among six different factors: Population Size (PS), Breeding Distribution (BD), Nonbreeding Distribution (ND), Threats to Breeding (TB), Threats to Nonbreeding (TN), and Population Trend (PT) (https://www.partnersinflight.org/resources/pif-watch-list-table-2016/). Nineteen species occur on the highest threat level (Red List), with three of these species occurring in the Northeast (Bicknell's thrush [Catharus bicknelli], goldenwinged warbler [Vermivora chrysoptera], and saltmarsh sparrow 
[Ammodramus caudacutus]). We have summarized bird species that inhabit or are likely to inhabit USACE reservoir lands in the NAD according to IPaC, and we ranked them according to the PIF's 2016 Watchlist (Table 2).

Table 2. Ranking of bird species by total vulnerability score on the Partners in Flight (PIF) 2016 Watchlist and that inhabit or potentially inhabit USACE reservoir properties within the NAD according to the US Fish and Wildlife Service (USFWS) IPaC report.

\begin{tabular}{|c|c|c|c|c|c|c|c|c|c|c|c|}
\hline Species & PS & BD & ND & TB & TN & PT & Total & $\begin{array}{l}\text { Red or } \\
\text { yellow } \\
\text { list }\end{array}$ & Habitat & $\begin{array}{l}\text { \# of USACE } \\
\text { reservoirs with } \\
\text { potential birds of } \\
\text { concern }\end{array}$ & $\begin{array}{l}\% \text { of USACE } \\
\text { reservoirs with } \\
\text { potential birds of } \\
\text { concern }\end{array}$ \\
\hline $\begin{array}{l}\text { Saltmarsh sparrow } \\
\text { Ammodramus caudacutus }\end{array}$ & 4 & 5 & 4 & 5 & 4 & 5 & 27 & Red & $\begin{array}{l}\text { Coastal } \\
\text { saltmarsh }\end{array}$ & 2 & 4 \\
\hline $\begin{array}{l}\text { Bicknell's thrush } \\
\text { Catharus bicknelli }\end{array}$ & 4 & 4 & 4 & 3 & 5 & 4 & 24 & Red & Boreal forest & 8 & 15 \\
\hline $\begin{array}{l}\text { Golden-winged warbler } \\
\text { Vermivora chrysoptera }\end{array}$ & 4 & 2 & 3 & 4 & 4 & 5 & 22 & Red & Eastern forest & 29 & 55 \\
\hline $\begin{array}{l}\text { Seaside sparrow } \\
\text { Ammodramus maritimus }\end{array}$ & 4 & 4 & 4 & 4 & 4 & 2 & 22 & Yellow & $\begin{array}{l}\text { Coastal } \\
\text { saltmarsh }\end{array}$ & 2 & 4 \\
\hline $\begin{array}{l}\text { Cerulean warbler } \\
\text { Setophaga cerulea }\end{array}$ & 3 & 2 & 3 & 4 & 4 & 5 & 21 & Yellow & Eastern forest & 38 & 72 \\
\hline $\begin{array}{l}\text { Henslow's sparrow } \\
\text { Ammodramus henslowii }\end{array}$ & 4 & 2 & 3 & 4 & 4 & 3 & 20 & Yellow & Grassland & 8 & 15 \\
\hline $\begin{array}{l}\text { Bobolink } \\
\text { Dolichonyx oryzivorus }\end{array}$ & 2 & 2 & 3 & 3 & 4 & 5 & 19 & Yellow & Grassland & 53 & 100 \\
\hline $\begin{array}{l}\text { Canada warbler } \\
\text { Cardellina canadensis }\end{array}$ & 3 & 2 & 2 & 3 & 4 & 5 & 19 & Yellow & Boreal forest & 53 & 100 \\
\hline $\begin{array}{l}\text { Eastern whip-poor-will } \\
\text { Caprimulgus vociferus }\end{array}$ & 3 & 2 & 3 & 3 & 3 & 5 & 19 & Yellow & Eastern forest & 34 & 64 \\
\hline $\begin{array}{l}\text { Kentucky warbler } \\
\text { Geothlypis formosa }\end{array}$ & 3 & 2 & 3 & 3 & 4 & 4 & 19 & Yellow & Eastern forest & 25 & 47 \\
\hline $\begin{array}{l}\text { Nelson's sparrow } \\
\text { Ammodramus nelsoni }\end{array}$ & 3 & 2 & 4 & 3 & 4 & 3 & 19 & Yellow & $\begin{array}{l}\text { Coastal } \\
\text { saltmarsh }\end{array}$ & 19 & 36 \\
\hline $\begin{array}{l}\text { Prothonotary warbler } \\
\text { Protonotaria citrea }\end{array}$ & 3 & 2 & 3 & 3 & 4 & 4 & 19 & Yellow & Eastern forest & 8 & 15 \\
\hline $\begin{array}{l}\text { Wood thrush } \\
\text { Hylocichla mustelina }\end{array}$ & 2 & 2 & 3 & 3 & 4 & 5 & 19 & Yellow & Eastern forest & 53 & 100 \\
\hline $\begin{array}{l}\text { Prairie warbler } \\
\text { Setophaga discolor }\end{array}$ & 3 & 2 & 2 & 3 & 3 & 5 & 18 & Yellow & Eastern forest & 53 & 100 \\
\hline $\begin{array}{l}\text { Black-billed cuckoo } \\
\text { Coccyzus erythropthalmus }\end{array}$ & 3 & 1 & 2 & 3 & 3 & 5 & 17 & Yellow & Eastern forest & 53 & 100 \\
\hline $\begin{array}{l}\text { Long-eared owl } \\
\text { Asio otus }\end{array}$ & 4 & 1 & 1 & 3 & 3 & 5 & 17 & Yellow & $\begin{array}{l}\text { Forest } \\
\text { generalist }\end{array}$ & 27 & 51 \\
\hline
\end{tabular}




\begin{tabular}{|c|c|c|c|c|c|c|c|c|c|c|c|}
\hline Species & PS & $B D$ & ND & TB & TN & PT & Total & $\begin{array}{l}\text { Red or } \\
\text { yellow } \\
\text { list }\end{array}$ & Habitat & $\begin{array}{l}\text { \# of USACE } \\
\text { reservoirs with } \\
\text { potential birds of } \\
\text { concern }\end{array}$ & $\begin{array}{l}\% \text { of USACE } \\
\text { reservoirs with } \\
\text { potential birds of } \\
\text { concern }\end{array}$ \\
\hline $\begin{array}{l}\text { Olive-sided flycatcher } \\
\text { Contopus cooperi }\end{array}$ & 3 & 1 & 1 & 3 & 4 & 5 & 17 & Yellow & Boreal forest & 15 & 28 \\
\hline $\begin{array}{l}\text { Red-headed woodpecker } \\
\text { Melanerpes erythrocephalus }\end{array}$ & 3 & 1 & 2 & 3 & 3 & 5 & 17 & Yellow & Eastern forest & 37 & 70 \\
\hline $\begin{array}{l}\text { Evening grosbeak } \\
\text { Coccothraustes vespertinus }\end{array}$ & 3 & 2 & 1 & 3 & 2 & 5 & 16 & Yellow & Boreal forest & 31 & 58 \\
\hline
\end{tabular}

\subsection{Biodiversity Information Serving Our Nation (BISON), US Geological Survey (USGS)}

The US Geological Survey (USGS) provides species occurrence data through a web-based mapping tool, Biodiversity Information Serving Our Nation (BISON), for all of the United States and its territories. BISON was first released in April 2013, with over 260 million records currently available through the Global Biodiversity Information Facility to provide freely available data for scientific research.

We used BISON to investigate species distribution in relation to specific habitats within the Landfire (NatureServe) land cover classification (see page 10). Models that link wildlife species to specific habitats likely perform best at predicting range shifts over time. For migratory species such as most species of birds, special attention to occurrence records must be considered, as many of these locations are only brief stopover sites between wintering and breeding grounds. Therefore, selecting only those locations that occur during a certain window of the year, such as the breeding season, may be preferable. However, if the goal is to focus on year-round occurrence or cycles such as wintering or stopover habitat, other time periods may be considered. 
Figure 2. A screenshot of the US Geological Survey (USGS) Biodiversity Information Serving Our Nation (BISON) web portal, demonstrating the capability to procure information on species' distributions and habitats.

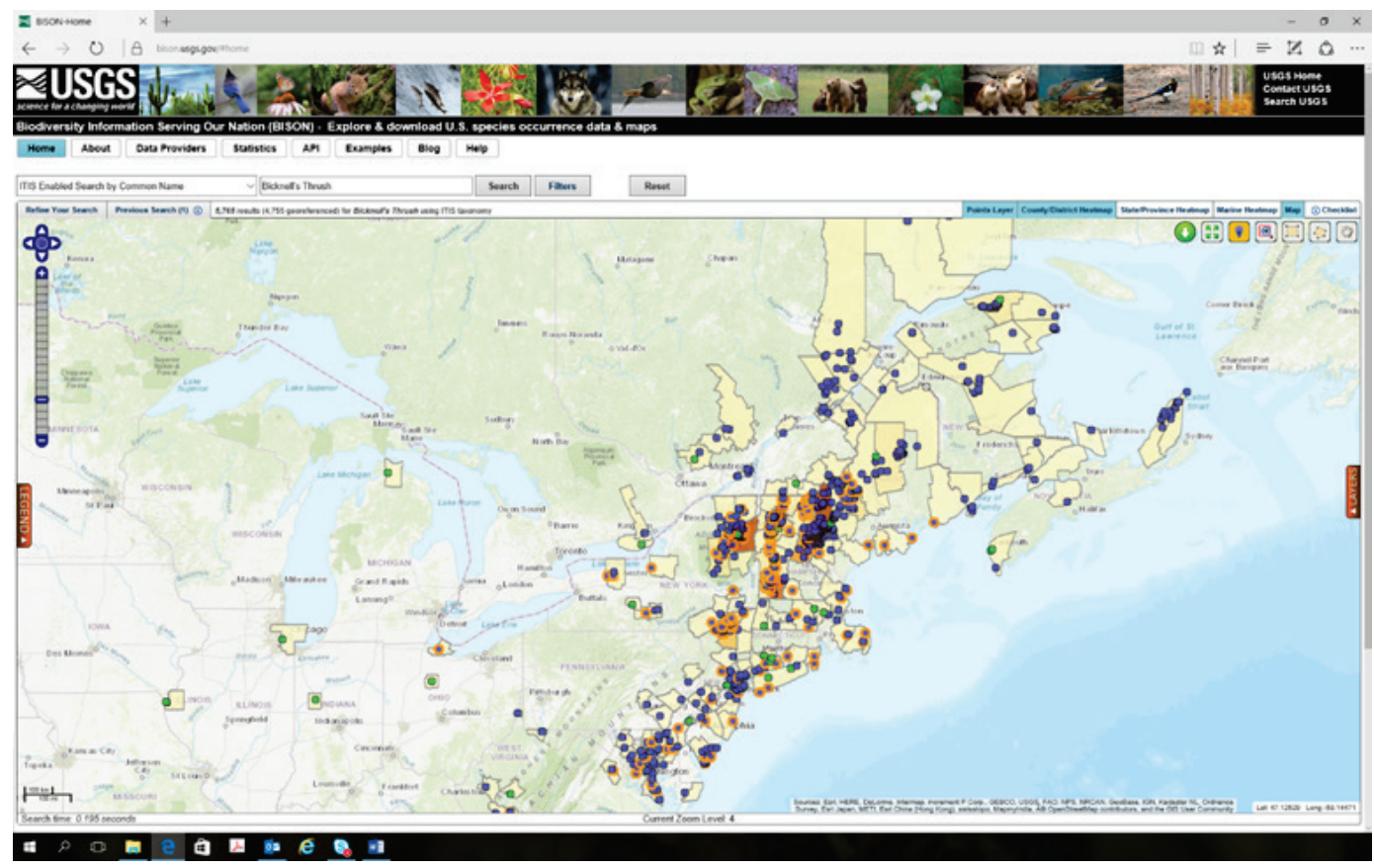

\subsection{Landfire (NatureServe)}

Landfire has adopted much of its vegetation community classification from the ecological systems created by NatureServe. NatureServe has generated approximately 600 ecological systems according to remote imagery and identifications by conservation and resource managers in the field. Terrestrial ecological systems, the focus of this modeling exercise, are specifically defined by the "plant community types that co-occur within the landscapes with similar ecological processes, substrates, and ... environmental gradients" (Comer et al. 2003 as cited in Popper et al. 2007, 20). Many species of wildlife, particularly TER-S, use specific habitats; therefore, we can link certain ecological systems in the NatureServe database to generalized species ranges. The USGS BISON web-based mapping tool that documents species' locations determines which habitats a species is most closely associated. For instance, Bicknell's thrush (Figure 3) is strongly dependent on the ecological system Acadian Appalachian Montane Spruce-Fir Forest, with approximately $62 \%$ of all breeding locations within that habitat unit (Table 3). 
Table 3. Percentage of breeding Bicknell thrush locations within each ecological system defined in the Landfire (NatureServe) Existing Vegetation Types.

\begin{tabular}{|l|l|}
\hline Ecological system (ES) & $\begin{array}{l}\text { Percent of } \\
\text { locations } \\
\text { within ES }\end{array}$ \\
\hline Acadian-Appalachian montane spruce-fir forest & 62 \\
\hline Laurentian-Acadian northern hardwoods forest & 17 \\
\hline Acadian-Appalachian alpine tundra & 8 \\
\hline $\begin{array}{l}\text { Acadian-Appalachian subalpine woodland and heath- } \\
\text { krummholz }\end{array}$ & 5 \\
\hline Developed-low intensity & 3 \\
\hline Acadian low-elevation spruce-fir-hardwood forest & 1 \\
\hline Developed-medium intensity & 1 \\
\hline Open water & 1 \\
\hline Developed-open space & 1 \\
\hline Central Appalachian dry oak-pine forest & 1 \\
\hline Laurentian-Acadian alkaline conifer-hardwood swamp & $<1$ \\
\hline Agriculture-pasture/hay & $<1$ \\
\hline Laurentian-Acadian wet meadow-shrub swamp & $<1$ \\
\hline Nonspecific disturbed & $<1$ \\
\hline Ruderal forest & $<1$ \\
\hline Boreal-Laurentian bog & $<1$ \\
\hline North-central interior wet meadow-shrub swamp & $<1$ \\
\hline
\end{tabular}


Figure 3. Locations and distribution of Bicknell's thrush in the USACE NAD overlaying the ecoregion land cover layer from Landfire (NatureServe).

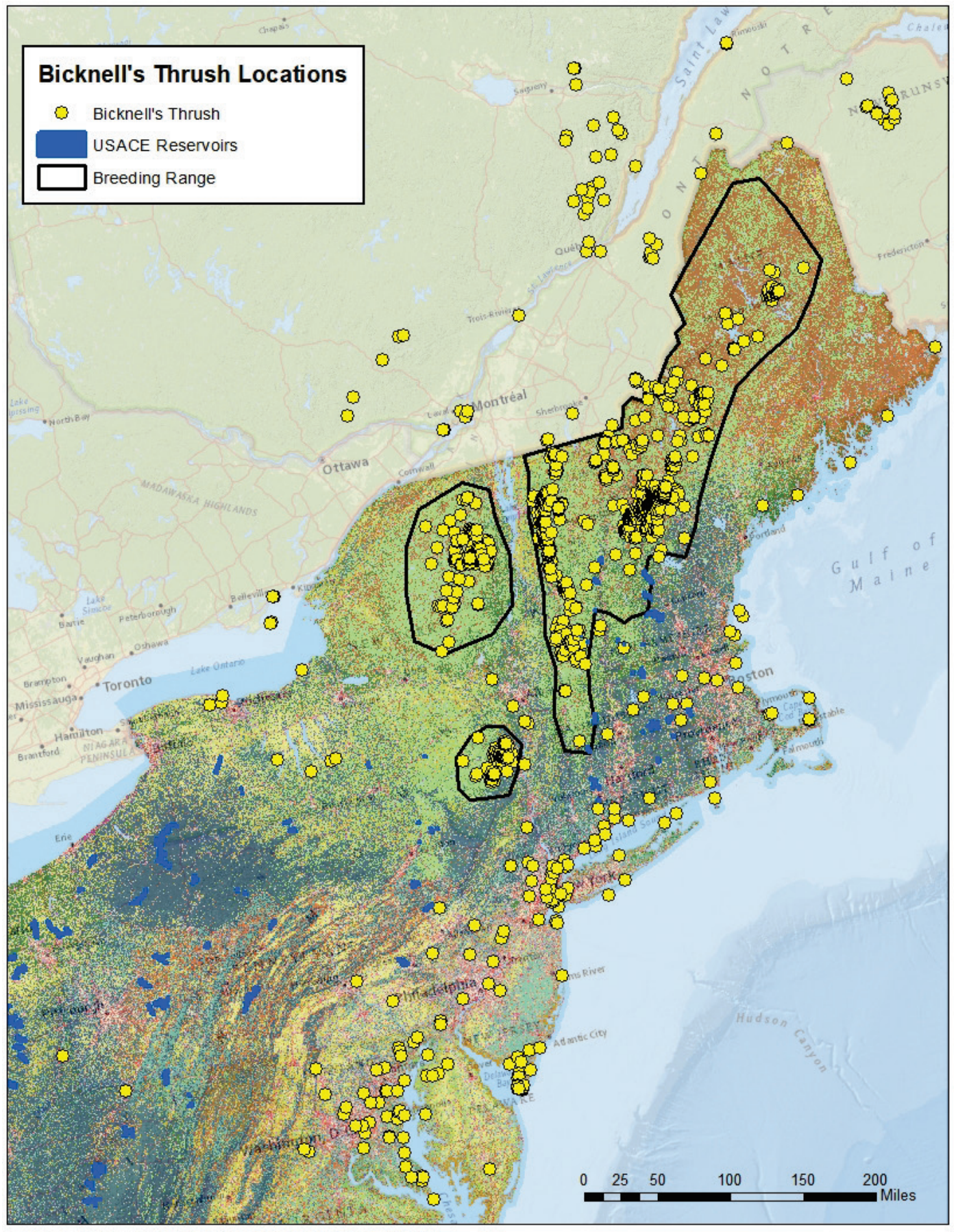




\section{Focal Species}

We have identified two species in the Northeast that are suitable representatives to demonstrate our climate change framework and species distribution model for the NAD: Bicknell's thrush (Catharus bicknelli) and Carolina northern flying squirrel (Glaucomys sabrinus coloratus). Descriptions of these species and reasons for selection as focal species in this effort are provided below. This model also can incorporate other species depending on the needs and objectives of NAD managers. We have selected these species because (1) they currently or in the future will likely pose a high expenditure for USACE; (2) they are of high conservation concern; (3) federal law mandates management of the species (for example, ESA); (4) they currently occur or likely will occur on USACE lands in the NAD in the future; and (5) they are species that associate strongly with particular sets of terrestrial habitats.

Some species of high concern, such as Indiana or Northern long-eared bats, are of special interests due to their large geographic range and cost expenditure for USACE. Bats are largely forest-dwelling species, and many species are found in the NAD-including many sensitive, declining, or listed species. However, many bats are declining due to infestation of the white-nose syndrome fungus (Pseudogymnoascus destructans) among hibernating bat populations, and declines are largely separate from global climate change impacts on habitat. Listing of these species are either associated with winter hibernacula or with disease that cannot be investigated within the current framework. As such, these species are not good candidates for this modeling effort; however, shifts in vegetation communities may still prove important to managers interested in future management efforts for these species. Likewise, many species that contribute to high expenditure for USACE are primarily aquatic and, therefore, not suitable candidates for this modeling effort, which focuses on terrestrial species, but they should be considered in future efforts that attempt to model shifts to aquatic habitats in the face of climate change.

Focal species selected for inclusion into the global climate change framework by Davis et al. (2019) were determined by several factors: (1) the species are specifically terrestrial species and found in high elevation forest habitats; this feature excludes all aquatic TER-S, of which many are found in the NAD along rivers and coastal areas; and (2) the species are already identified as species at risk by national or regional organizations. 
Many USACE project lands in the NAD are in mountainous regions and are imbedded in largely forested, upland habitat matrix. Like most USACE project lands, NAD project managers enact natural resource management and restoration efforts on the lands around these reservoirs, and they are responsible for efforts to monitor and manage TER-S within their jurisdiction. The global climate change framework will determine shifts in forest distribution in high elevation conditions; therefore, selected focal species include those dependent upon the existing forested conditions.

\subsection{Bicknell's thrush (Catharus bicknelli)}

The Bicknell's thrush (Figure 4) is already part of the native bird community in the NAD. This species is recognized as a sensitive high elevation species (Rimmer et al. 2001) likely susceptible to changes brought by global climate change. The range of this species is already part of the NAD (Figure 3), and the species can be detected in and around several USACE project lands. This species is identified by PIF as a regionally sensitive species (Rosenberg et al. 2016). The potential for global climate change to cause habitat shifts in high elevation forests could further erode this bird's population in the region, leading to potential listing under ESA, as has already been proposed in the past. This species typically uses forests with balsam fir (Abies balsamea) and spruce (Picea spp.); however, according to some climate forecasting models, global climate change will reduce these forests by up to 90\% (Iverson et al. 1999). The listing of this species could alter the current natural resource management efforts by USACE NAD, and management of this species could increase overall expenditure.

Figure 4. The Bicknell's thrush is an uncommon, high elevation species found in the NAD region that may be sensitive to global climate change (Photo Credit: Tim Laman/Audubon).

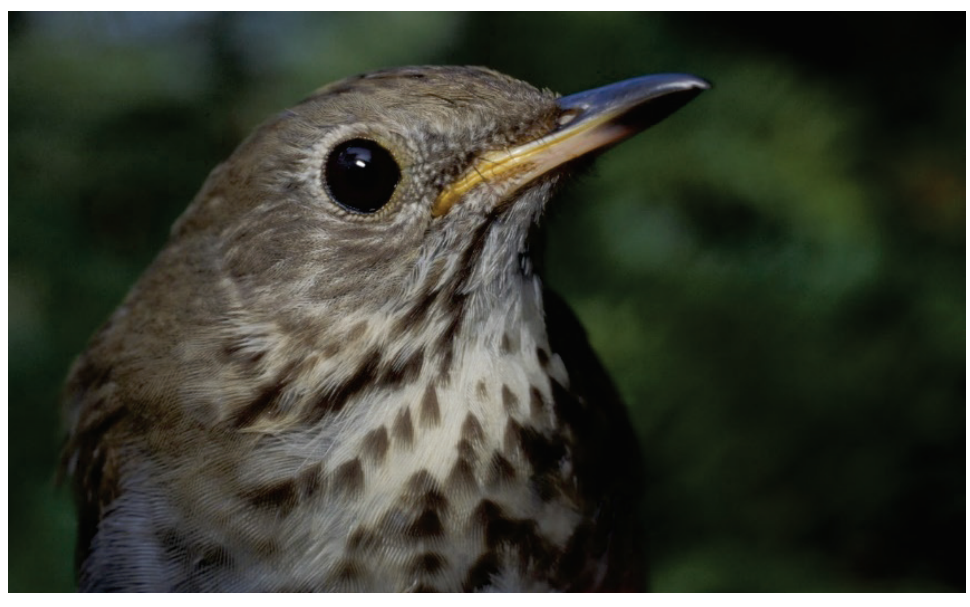




\subsection{Carolina northern flying squirrel (Glaucomys sabrinus coloratus)}

The Carolina northern flying squirrel is a subspecies of the Northern flying squirrel (Glaucomys sabrinus) (Figure 5). This subspecies occurs in the high elevation Appalachian Mountains in North Carolina, West Virginia, and Eastern Tennessee. This species was listed as endangered by the USFWS in 1985, and its endangered status was upheld during the most recent USFWS 5-year review (USFWS 2013). While this species is found south of the NAD, the species could shift north due to climate change. Global climate change has already yielded hybridization between northern and southern flying squirrel populations in Canada (Garroway et al. 2010); it is possible that the federally listed Carolina northern flying squirrel could shift northward into the NAD. Therefore, this species is a good candidate for investigating how a species currently not a concern to a region may become a priority in the future. Climate change models that can predict if this shift will occur within the USACE planning horizon will assist managers preparing to incorporate restoration into existing plans. If this species were to shift distribution into the southern portions of the $\mathrm{NAD}$, it could alter current management priorities due to its endangered status. Moreover, movement of this species into the NAD could increase hybridization rates among other flying squirrel species and subspecies, potentially diluting subspecies populations and leading to potential extinction of the Carolina northern flying squirrel as a subspecies.

Figure 5. The Carolina northern flying squirrel is a federally listed species that could shift into the USACE NAD jurisdiction as a result of global climate change (Photo Credit: USFWS).

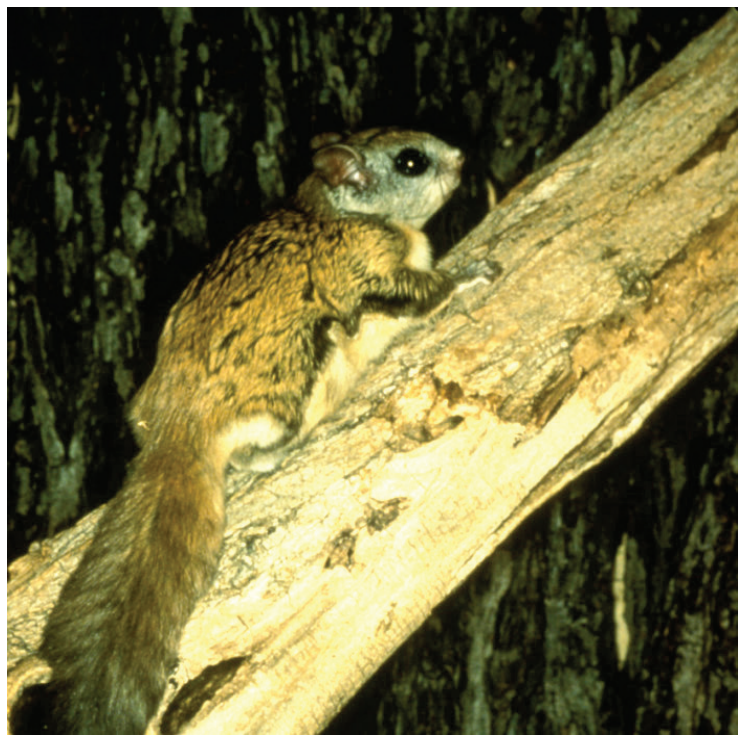




\section{Invasive Species}

Non-native species introduced into the North Atlantic region might further degrade habitats for TER-S. Fiscal expenditures on management of TER-S may be much less than expenditures on controlling or eradicating non-native invasives (Pimentel et al. 2000, Pimentel, Zuniga, and Morrison 2005). A proactive approach for management of TER-S will need to include understanding the potential impacts of existing non-native species in the region. Climate change models often project scenarios where existing non-native species will spread (Huang, Haack, and Zhang 2011) or where new invasives will be introduced and become naturalized into the North American fauna (Hellmann et al. 2008; Mainka and Howard 2010). Therefore, any models that predict the effects of climate change on TER-S will need to include potential impacts of invasive species. Since predicting future introductions of potentially damaging invasives is difficult, we will focus only on those invasive species that are already known to exist in the NAD. We used the Operations and Management Business (OMB) line of the Department of Defense to determine the distribution of invasive species on USACE NAD project lands. We then used NatureServe rankings of invasive species to determine those species most likely to affect the distribution of TER-S.

We focused on terrestrial invasive plant species that might impact the structure and function of forested habitats in the North Atlantic. We only used species ranked as High or Medium High by NatureServe for their potential impacts on habitats in the Northeast. Of those species, we focused on those that ranked High in at least two of the three categories of impacts. The three categories we focused on include (1) impact on ecological processes, (2) impact on community structure, and (3) impacts on community composition (Table 4). We highlighted invasive species that ranked highly in these categories, since these species would be the most likely to negatively affect the structure and function of forested habitats used by TER-S in the NAD.

We found 10 terrestrial invasive species that met these criteria (Table 4). Since our final selection of TER-S are species that use mature to immature forested habitats, we chose to include those invasive tree species most likely to negatively affect such habitats in the NAD while excluding grasses and forbs. These species include autumn olive (Elaeagnus umbellata), 
black locust (Robinia pseudoacacia), common buckthorn (Rhamnus cathartica), and Norway maple (Acer platanoides) (Table 4).

The spread of invasives due to climate change also may be linked to increased fragmentation of terrestrial forested habitats (Opdam and Wascher 2004) due to increased urbanization in the Northeast (Hung, Ascher, and Holway 2017). Therefore, we will model predicted spread of urbanization in the Northeast. Disturbance events, such as fire or timber harvest, can set back succession to an early stage, thereby allowing for the invasion of non-native species into these areas. The final model will provide a paradigm for predicting impacts of global climate change on the selected TER-S by examining how global climate change will alter ecological conditions on forested habitats in the Northeast, including the potential for spread of invasive species, and examining the predicted continual increase in habitat fragmentation due to increased urbanization and other disturbance events in the region.

Table 4. Invasive terrestrial plants in the NAD highly ranked by the US Forest Service and likely to negatively affect selected focal species (NatureServe 2017).

\begin{tabular}{|c|c|c|c|c|c|}
\hline Species & Scientific name & $\begin{array}{l}\text { NatureServe } \\
\text { rank }\end{array}$ & $\begin{array}{l}\text { Impact on } \\
\text { ecological } \\
\text { process }\end{array}$ & $\begin{array}{l}\text { Impact on } \\
\text { ecological } \\
\text { community } \\
\text { structure }\end{array}$ & $\begin{array}{l}\text { Impact on } \\
\text { ecological } \\
\text { community } \\
\text { composition }\end{array}$ \\
\hline Autumn olive* & $\begin{array}{l}\text { Elaeagnus } \\
\text { umbellata }\end{array}$ & High & High & Low-Medium & High \\
\hline Crowned vetch & Securigera varia & High & $\begin{array}{l}\text { Medium- } \\
\text { High }\end{array}$ & High & High \\
\hline Scotch broom & Cytisus scoparius & High & High & Medium & High \\
\hline Black locust* & $\begin{array}{l}\text { Robinia } \\
\text { pseudoacacia }\end{array}$ & $\begin{array}{l}\text { Medium- } \\
\text { High }\end{array}$ & High & High & Medium \\
\hline $\begin{array}{l}\text { Common } \\
\text { buckthorn }\end{array}$ & $\begin{array}{l}\text { Rhamnus } \\
\text { cathartica }\end{array}$ & $\begin{array}{l}\text { Medium- } \\
\text { High }\end{array}$ & Medium & High & High \\
\hline $\begin{array}{l}\text { Japanese } \\
\text { honeysuckle }\end{array}$ & Lonicera japonica & $\begin{array}{l}\text { Medium- } \\
\text { High }\end{array}$ & $\begin{array}{l}\text { Insignificant- } \\
\text { Low }\end{array}$ & High & High \\
\hline $\begin{array}{l}\text { Morrows (bush) } \\
\text { honeysuckle }\end{array}$ & Lonicera morrowii & $\begin{array}{l}\text { Medium- } \\
\text { High }\end{array}$ & Insignificant & High & High \\
\hline Norway maple* & Acer platanoides & $\begin{array}{l}\text { Medium- } \\
\text { High }\end{array}$ & Insignificant & High & High \\
\hline $\begin{array}{l}\text { Oriental } \\
\text { bittersweet }\end{array}$ & $\begin{array}{l}\text { Celastrus } \\
\text { orbiculatus }\end{array}$ & $\begin{array}{l}\text { Medium- } \\
\text { High }\end{array}$ & Low & High & High \\
\hline Winter creeper & $\begin{array}{l}\text { Eounymus } \\
\text { fortunei }\end{array}$ & $\begin{array}{l}\text { Medium- } \\
\text { High }\end{array}$ & Low & High & High \\
\hline
\end{tabular}




\section{Summary}

This special report describes the selection process for determining the inclusion of TER-S in a climate change model framework by Davis et al. (2019). We have focused our efforts on high-elevation montane habitats in the USACE North Atlantic Division. We used information from the USACE Threatened and Endangered Species Team web portal to obtain information on budgetary costs of these species in the region. We used the USFWS's IPaC to procure information on complying with NEPA and ESA for listed species and other sensitive biological resources in the region. PIF provided data on migratory birds in the region that are sensitive or at risk and may be candidates for future listing under ESA, and we used the USGS's BISON and NatureServe LandFire resources to identify species' distribution and habitats within the existing land cover classification.

This information permits us to link wildlife species to specific habitats likely to be affected by global climate change. After assessing these data, we chose one rare, sensitive migratory bird, Bicknell's thrush (Catharus bicknelli), and an endangered subspecies, the Carolina northern flying squirrel (Glaucomys sabrinus coloratus), as our target species. Global climate change likely will affect the spread of invasive species and promote the invasion of additional invasive species. Therefore, we used data from NatureServe (2017) to identify those invasive species most likely to affect the ecological processes, community structure and composition for highelevation forested habitats in the North Atlantic. These species include autumn olive (Elaeagnus umbellata), black locust (Robinia pseudoacacia), common buckthorn (Rhamnus cathartica) and Norway maple (Acer platanoides). These species are likely to greatly affect the landscape as climate change alters vegetation communities and as other disturbance events modifying the landscape, creating a greater pathway for invasion by these species. These focal species and habitat associations will be included in the climate change framework by Davis et al. (2019) to develop predictive models on the impacts of climate change on TER-S and the potential to effect land management decisions by USACE project managers in the NAD. Once demonstrated as successful, the model can be applied to other species and in other regions nationwide. 


\section{References}

Baltensperger, A. P., and F. Huettmann. 2015. "Predicted shifts in small mammal distributions and biodiversity in the altered future environment of Alaska: an open access data and machine learning perspective." PlosOne 10: e0132054.

Bellard, C., C. Bertelsmeier, P. Leadley, W. Thuiller, and F. Courchamp. 2012. "Impacts of climate change on the future of biodiversity." Ecological Letters 15:365-377.

Carey, C. 2009. "The impacts of climate change on annual cycles of birds." Philosophical Transactions of the Royal Society 364: 3321-3330.

Comer, P., D. Faber-Langendoen, R. Evans, S. Gawler, C. Josse, G. Kittel, S. Menard, M. Pyne, M. Reid, K. Schulz, K. Snow, and J. Teague. 2003. "Ecological Systems of the United States: A Working Classification of U.S. Terrestrial Systems" NatureServe, Arlington, Virginia.

Davis, A. V., A. Fuentes, J. F. Jung, H. Theel, E. Britzke, and R. A. Fischer. 2019. "Tools for predicting wildlife species distribution response to ecological shifts.” EMRRP Technical Notes Collection, ERDC/TN EMRRP-EI-05. Vicksburg, MS: U.S. Army Engineer Research and Development Center.

Endangered Species Act of 1973, 16 U.S.C. $35 \S 1531$ et seq. (1751). https://www.govinfo.gov/content/pkg/USCODE-2018-title16/pdf/USCODE-2018-title16chap35-sec1533.pdf.

Garroway, C. L., J. Bowman, T. J. Cascaden, G. L. Holloways, C. G. Mahan, J. R. Malcolm, M. A. Steele, G. Turner, and P. J. Wilson 2010. "Climate change induced hybridization in flying squirrels.” Global Change Biology 16:113-121.

Gill, J. A., J. A. Alves, W. J. Sutherland, G. F. Appleton, P. M. Potts, and T. G. Gunnarsson. 2014. "Why is timing of bird migration advancing when individuals are not?" Proceedings of the Royal Society 281: 20132161. http://dx.doi.org/10.1098/rspb.2013.2161.

Hellmann, J. J., J. E. Byers, B. G. Bierwagen, and J. S. Dukes. 2008. "Five potential consequences of climate change.” Conservation Biology 22:534-543.

Huang, D., R. A. Haack, and R. Zhang. 2011. "Does global warming increase establishment rates of invasive alien species? A centurial time series analysis." PlosOne 6(9): e24733. Doi:10.1371/jounal.pone.0024733.

Hung, K-L. J., J. S. Ascher, and D. A. Holway. 2017. "Urbanization-induced habitat fragmentation erodes multiple components of temporal diversity in a Southern California native bee assemblage." PlosOne 12(8): e0184136. Doi:10.1371/journal.pone.0184136.

Iverson, L. R., A. M. Prasad, B. J. Hale, and E. K. Sutherland. 1999. An atlas of current and potential future distributions of common trees of the eastern United States. General Technical Report, NE-265, Northeast Research Station, U.S. Department of Agriculture, Forest Service. 
Kirby, J. S., A. J. Stattersfield, S. H. M. Butchart, M. J. Evans, R. F. A. Grimmett, V. R. Jones, J. O'Sullivan, G. M. Tucker, and I. Newton. 2008. "Key conservation issues for migratory land- and waterbird species on the world's major flyways." Bird Conservation International 18:S49-S73.

Mainka, S. A., and G. W. Howard. 2010. "Climate change and invasive species: double jeopardy.” Integrative Zoology 5:102-111.

Monzon, J., L. Moyer-Horner, and M. B. Palamar. 2011. "Climate change and species range dynamics in protected areas.” BioScience 61:752-761.

Moss, R., J. Edmonds, K. Hibbard, M. Manning, S. Rose, D. van Vuuren, T. Wilbanks. 2010. "The next generation of scenarios for climate change research and assessment." Nature, 463(11), 747-756. doi:10.1038/natureo8823.

National Environmental Policy Act of 1969, 42 U.S.C. $55 \S 4321$ et seq. (5211). https:// www.govinfo.gov/content/pkg/USCODE-2010-title42/pdf/USCODE-2010-title42-chap55sec4321.pdf.

NatureServe. 2017. NatureServe Data, Maps \& Tools. Retrieved from NatureServe: http://www.natureserve.org/conservation-tools/data-maps-tools.

Opdam, O., and D. Wascher. 2004. "Climate change meets habitat fragmentation: linking landscape and biogeographical scale levels in research and conservation." Biological Conservation 117:285-297.

Parmesan, C., Yohe. 2003. "A globally coherent fingerprint of climate change impacts across natural systems." Nature 421: 37-42.

Pimentel, D., R. Zuniga, and D. Morrison. 2005. "Update on the environmental and economic costs associated with alien-invasive species in the United States." Ecological Economics 52: 273-288.

Pimentel, D. R., L. Lach, R. Zuniga, and D. Morrison. 2000. "Environmental and economic costs of nonindigenous species in the United States." Bioscience 50:5365 .

Popper, K., G. Wilhere, M. Schindel, D. VanderSchaaf, P. Skidmore, G. Stroud, J. Crandall, J. Kagan, R. Crawford, G. Kittel, J. Azerrad, L. Bach. 2007. The East Cascades - Modoc Plateau and West Cascades Ecoregional Assessments. Prepared by The Nature Conservancy and the Washington Department of Fish and Wildlife with support from the Oregon Natural Heritage Information Center, Washington Heritage Program, and Natureserve. The Nature Conservancy, Portland, Oregon.

Rimmer, C. C., K. P. McFarland, W. G. Ellison, and J. E. Goetz. 2001. Bicknell's Thrush (Catharus bicknelli). In The Birds of North America, No. 592 (A. Poole and F. Gill, eds.). Philadelphia, PA: The Birds of North America, Inc. 
Rosenberg, K. V., J. A. Kennedy, R. Dettmers, R. P. Ford, D. Reynolds, J.D. Alexander, C. J. Beardmore, P. J. Blancher, R. E. Bogart, G. S. Butcher, A. F. Camfield, A. Couturier, D. W. Demarest, W. E. Easton, J.J. Giocomo, R.H. Keller, A. E. Mini, A. O. Panjabi, D. N. Pashley, T. D. Rich, J. M. Ruth, H. Stabins, J. Stanton, T. Will. 2016. "Partners in Flight Landbird Conservation Plan: 2016 Revision for Canada and Continental United States.” Partners in Flight Science Committee, $119 \mathrm{pp}$.

Thomas, C. D. 2010. "Climate, climate change and range boundaries." Diversity and Distributions 16: 488-495. doi:10.1111/j.1472-4642.2010.00642.x.

US Fish and Wildlife Service (USFWS). 2013. "Carolina Northern Flying Squirrel (Glaucomys sabrinus coloratus), 5-Yer Review: Summary and Evaluation.” US FWS, Southeast Region, Ashville Ecological Services Field Office, Ashville, NC.

Visser, M. E., and C. Both. 2005. "Shifts in phenology due to global climate change: the need for a yardstick." Proceedings of the Royal Society 272: 2561-2569. 


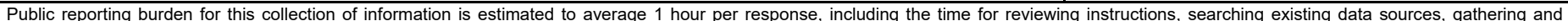

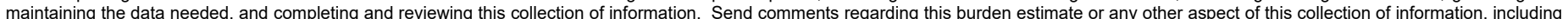

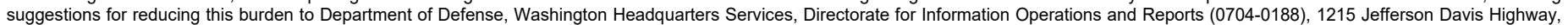

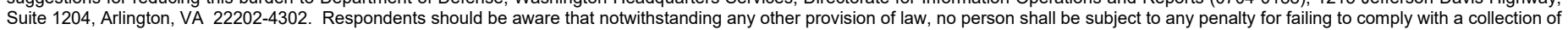
information if it does not display a currently valid OMB control number. PLEASE DO NOT RETURN YOUR FORM TO THE ABOVE ADDRESS.

\begin{tabular}{|l|l|l} 
1. REPORT DATE (DD-MM-YYYY) & 2. REPORT TYPE & 3. DATES COVERED (FrOm - To)
\end{tabular}

September 2021

Special Report

4. TITLE AND SUBTITLE

Threatened, Endangered, and At-Risk Species for Consideration into Climate Change

Models in the Northeast

5a. CONTRACT NUMBER

5b. GRANT NUMBER

5c. PROGRAM ELEMENT NUMBER

6. AUTHOR(S)

Jacob F. Jung, Michael P. Guilfoyle, Austin V. Davis, Christina L. Saltus,

Eric R. Britzke, and Richard A. Fischer

5d. PROJECT NUMBER

5e. TASK NUMBER

5f. WORK UNIT NUMBER

7. PERFORMING ORGANIZATION NAME(S) AND ADDRESS(ES)

US Army Engineer Research and Development Center

Environmental Laboratory Geotechnical Structures Laboratory

3909 Halls Ferry Road 3909 Halls Ferry Road

Vicksburg, MS $39180 \quad$ Vicksburg, MS 39180

8. PERFORMING ORGANIZATION REPORT NUMBER

ERDC SR-21-7

9. SPONSORING / MONITORING AGENCY NAME(S) AND ADDRESS(ES)

U.S. Army Corps of Engineers, Ecosystem Management and Restoration

Research Program

3909 Halls Ferry Road

Vicksburg, MS 39180

12. DISTRIBUTION / AVAILABILITY STATEMENT

Approved for public release; distribution is unlimited.

\section{SUPPLEMENTARY NOTES}

AMSCO for this work is 031342 ; the funding account is U4368936.

\section{ABSTRACT}

This special report provides a selection process for choosing priority species using the specific focus of high-elevation, forested habitats in the North Atlantic to demonstrate the process. This process includes criteria for choosing invasive species to incorporate into models, given the predicted spread of invasive plant species because of climate change. Discussed in this report are the US Army Corps of Engineers' Threatened and Endangered Species Team portal, the US Fish and Wildlife Service's Information for Planning and Consultation Portal, the nonprofit organization Partners in Flight's watch list, the US Geological Survey's

Biodiversity Information Serving Our Nation model, and NatureServe's interagency effort Landfire. The data linked this montane habitat with a species of conservation concern, Cartharus bicknelli and the endangered squirrel Glaucomys sabrinus as target species and with Elaeagnus umbellate, Robinia pseudoacacia, Rhamnus cathartica, and Acer planoides as invasive species. Incorporating these links into the climate change framework developed by Davis et al. (2018) will create predictive models for the impacts of climate change on TER-S, which will affect land management decisions in the region.

\section{SUBJECT TERMS}

Endangered species--United States--Northeastern States Military bases Environmental management

Endangered species--Habitat--Climatic factors Climatic changes

\section{SECURITY CLASSIFICATION OF:}

\begin{tabular}{|l|c|c|}
\hline $\begin{array}{l}\text { a. REPORT } \\
\text { Unclassified }\end{array}$ & $\begin{array}{c}\text { b. ABSTRACT } \\
\text { Unclassified }\end{array}$ & $\begin{array}{r}\text { c. THIS PAGE } \\
\text { Unclassified }\end{array}$ \\
\hline
\end{tabular}

\begin{tabular}{c|c|}
$\begin{array}{c}\text { 17. LIMITATION } \\
\text { OF ABSTRACT }\end{array}$ & $\begin{array}{c}\text { 18. NUMBER } \\
\text { OF PAGES }\end{array}$ \\
SAR & 31 \\
\hline
\end{tabular}

19a. NAME OF RESPONSIBLE PERSON

19b. TELEPHONE NUMBER (include area code) 